\title{
GEMSTONE FEVER HITS JAKARTA: A LEXICAL MEANING ANALYSIS
}

\author{
Soraya Grabiella Dinamika \\ Universitas Sumatera Utara \\ soraya.dinamika@gmail.com
}

\begin{abstract}
The objective of this study is to find out the use of semantic relation in analyzing the lexical meaning in article "Gemstone Fever Hits Jakarta". There are some semantic relations found frequently in the article namely, the use of synonymy, polysemy, homonymy, and hyponymy. This study was conducted by using qualitative research. The data suorce of this study was obtained from the words existed in the article of "Gemstone Fever Hits Jakarta." The total number of words occurred in the article is 546 words. After being analyzed, it was found that the article contained of 34 synonymies; 10 homonymies; 10 Polysemies and 12 Hyponymies, therefore the total number of words which have semantic relation is 68 . It is obviously identified that the article of "Gemstone Fever Hits Jakarta" contained mostly of synonym words, which means most of the lexical meaning of the words had the same meaning in the context.
\end{abstract}

\section{Keyword: lexical meaning, semantic relation, article}

\section{A. INTRODUCTION}

Finding the meaning of a word in a given language by using dictionary is common activity which is usually done by the learners to find out the word which mean hasn't been revealed by them. This kind of study is conducted in an area of semantics known as lexical semantics. For most people, word meanings are most closely associated with dictionaries, a general reference guide for meaning and other matters, such as spelling, that people consult from their earliest years in school through adulthood.

Even though, to look up the meaning of English word from dictionary has already been old activity, it is still done by many people until today, to find out the meaning of words which occurred in the written text book, speech text, song, poem, movie script and etc. It is proven by the development of English dictionaries itself, such as; Oxford English Dictionary (OED), Merriam-Webster's Collegiate Dictionary, 
American Heritage Dictionary of the English Language (AHD), Collins Dictionary of the English Language, Longman Dictionary of the English Language (LDEL and Roget's Thesaurus.

What does it mean by the term 'word' in lexicology?. This question is not easy to answer as the linguists an lexicographer are still debating about its actual meaning. But, lexicology comes from Greek lexis 'word', lexicos 'of/for words'. Jackson (2000:185) defined it as the branch of linguistics that investigates, describes and theorizes about vocabulary.

All languages do have words, it is an ideal reason as a dictionary of given language contains of all the words in the vocabulary of that language. Amvela (2000:50) considered the word as an uninterruptible unit of structure consisting of one or more morphemes and which typically occurs in the structure of phrases.

Most fluent speakers of English seem to know what a word is. They know, for example, that words are listed in the dictionaries, that they are separated in writing by spaces, and that they may be separated in speech by pauses. The dictionary-words are technically called as 'lexeme'. Lyons (1995:47) defines a lexeme as a lexical unit: a unit of the lexicon. Lexicon has the same meaning with dictionary or vocabulary.

After questioning of words existed; what is meaning? What does it mean when someone says, "I know the meaning of this word"? Those utterances often occur in daily conversation, but there is still misunderstanding in interpreting what meaning exactly is. Meaning comes out from a word. The noun 'meaning' and the verb 'mean', from which it is derived, are used, like many other English words, in a wide range of contexts and in several distinguishable senses. Mean - intend to express or convey.

The writer has been interested to analyze the lexical meaning in an article of gemstone fever in Indonesia now. There are some of the semantic relations which can 
be used to analyzed the typical of lexical item, such as; homonymy, polysemy, synonymy, antonymy, meronymy, hyponymy and etc.

As related to the background of study above, the writer formulated the problem of study as: "How is the analysis of the lexical meaning in Article 'Gemstone Fever Hits Jakarta" by using the semantic relation?"

The objective of this study is to find out the use of semantic relation in analyzing the lexical meaning in article "Gemstone Fever Hits Jakarta". There are some semantic relations which are provided in semantic namely, synonymy, antonymy, meronymy, hyponymy and etc. But, this study is limited only in the use of synonymy, polysemy, homonymy, and hyponymy. As those semantic relations are found frequently in the article.

\section{B. RELATED LITERATURE}

This chapter presents brief explanation of the related materials, which is aimed at giving some clarifications of the terms used in this study. The terms are defined in order to avoid misunderstanding that might occur in the process of getting a better insight of the discussion of the study.

\section{a. Lexical Semantic (Words Meaning)}

Fromkin (2011:140) defines lexical semantics as the subfield of semantics concerned with the meanings of words and the meaning relationships among words.

Curse in Meyer (1986:16) defines lexical semantics as determinate set of paradigmatic and syntagmatic] relations; nevertheless, such relations contribute to wordsenses and are presented in Lexical Semantics as the means through which to investigate lexical meaning. 


\section{b. Reference}

Saussure in Saeed (1997:12) states that words stand in a relationship to the world, or our mental classification of it: they allow us o identify parts of the world, and make statements about them. If a speaker say $\underline{\mathrm{He}}$ saw $\underline{\text { Paul }}$, the underlined nominals identify, pick out, or refer to specific entities in the world.

Rodman (2011:154) states that the meaning of a word or expression is its reference, its association with the object it refers to. This real world object is called the referent. In the sentence, Jack swims, the word Jack, which is a proper name, refers to a precise object in the world, which is its referent. For instance, in the scenario given earlier, the referential meaning of Jack is the guy who is your friend and who is swimming happily in the pool right now. Based on this, we conclude that the meaning of the name Jack is the individual it refers to.

\section{c. Sense}

Lyons (1995:80) defines sense as the set, or network, of sense relations that hold between it and other expressions of the same language. The 'lexeme' dog, denotes a class of entities in the external world. But it is also related to other lexemes and expressions of the same language-system (English), including 'animal', 'hound', 'spaniel', etc.

Jackson (2000:91) defines sense as relations hold between words within the vocabulary. The two most obvious sense relations are those of 'sameness' and 'oppositeness', called synonymy and antonymy. Other sense relations - hyponymy, meronymy - relate words hierarchilly, showing how a word with a general meaning includes the meaning of other words with more specific meanings. 


\section{d. Semantic Relation}

A discussion of meaning often begins by drawing a distinction between the 'reference' of a word and the 'sense' of a word. There are number of semantic relation, a particular lexeme may be simultaneously in a number of these relations, so that it may be more accurate to think of the lexicon as a network, rather than a listing of words as in a published dictionary. An important organizational principle in the lexicon is the lexical field. Dictionaries recognize the effect of lexical fields by including entries labels like banking, medicine etc.

\section{e. Synonymy}

Expressions with the same meaning are synonymous. It doesn't restrict the relation of synonymy to lexemes and it makes identity, not merely similarity, of meaning the criterion of synonymy. Lyons (1995:61) classify two or more expressions are absolutely synonymous, if and only if, they satisfy these three conditions:

(i) All their meanings are identical;

(ii) They are synonymous in all contexts;

(iii) They are semantically equivalent (i.e., their meaning or meanings are identical) on all dimensions of meaning, descriptive and non-descriptive.

Meyer (2009:170) defines synonymy as a semantic relation that has been extensively studied. The true test of synonymy is substitutability: the ability of two words to be substituted for one another without a change in meaning. For instance, the example below contains the verb assist. If help is a synonym of assist, then it should be able to be substituted for assist in the above example without a change in meaning. There are no words which identically same in the meaning, if it exist, it is quite rare. Because if words were truly synonymous they would need to "be able to be substituted 
one for the other in any context in which their common sense is denoted with no change to truth value, communicative effect, or 'meaning' (however 'meaning' is defined)."

\section{f. Homonymy}

Homonyms are traditionally defined as different words with the same form. Homonyms refer to a situation where we have two or more words with the same shape. Although they have the same shape, homonyms are considered distinct lexemes, mainly because they have unrelated meanings and different etymologies. Because of the sameness of shape, there is a danger of homonymous conflict or clashes in the sense that two homonyms with totally different meanings may both take sense in the same utterance. For example, route, root, and right, write.

However, there are at least two different safeguard against any possibility of confusion: the difference in word class and the difference in spelling, besides the difference in overall context, Jackson (2000:62).

\section{g. Polysemy}

Polysemy refers to the situation where the same word has two or more different meanings. Polysemy deals with multiple senses of the same phonological word, it is invoked if the senses are judged to be related. Saeed (1997:64) states that Lexicographers tend to use criteria of 'relatedness' to identify polysemy. These criteria include speakers' intuitions, and what is known about historical development of the items. 


\section{h. Hyponymy}

Meyer (2009:170) defines hyponymy a relation in which the meaning of a word is included in the meaning of a more general word (e.g. daisy, rose, tulip $\rightarrow$ flowers; desk, table, sofa $\rightarrow$ furniture; sparrow, robin, crow $\rightarrow$ birds). Poodle is a hyponym of $d o g$ because the meaning of poodle is included within the more general meaning of $d o g$.

In the relation of hyponymy, the more specific word is known as a hyponym and the more general word a hypernym. Words such as poodle, basset hound, and golden retriever are considered co-hyponyms because their meanings are all included within the meaning of $d o g$, and each of these words is of equal specificity: they are all "types of" dogs. Because dog is more general than poodle or basset hound, it would be considered a hypernym of these words.

\section{i. Dictionary}

Jackson (2000: 161) states that dictionaries contain information about words. They are the most systematic and comprehensive lexical descriptions that people have. If you want to find out something about a word, for example its spelling or its meaning, people would reach for a dictionary and search through the alphabetical list of headwords until you located the item you wanted to know about. By the half of the twentieth century, dictionary was quite independent of developments in linguistics. Meyer (2009:158) has listed several kinds of dictionary which has been developed until today, such as:

1. Monolingual dictionaries: Monolingual dictionaries are intended for native speakers and as a consequence focus on a single language (e.g. English, German, French). Some of the more well-known monolingual English dictionaries include the Oxford 
English Dictionary, Webster's Third New International Dictionary, and the American Heritage Dictionary of the English Language.

2. Thesauruses: These are dictionaries that specialize in providing synonyms for the main entries that they contain. One of the more famous English Thesauruses is Roget's Thesaurus, published in 1852 and writtenby Peter Roget.

3. Bilingual dictionaries: Bilingual dictionaries focus on two languages and are designed for individuals who are native speakers of a particular language learning another language as an additional language. For English speakers, there are English/Spanish dictionaries, English/Italian dictionaries.

In this study, the writer decided to use Oxford Learners' Dictionary Edition Four as it is simple style to look up the words list and easy to understand the meaning of every words. It is also provides adequate information as much as the writer needed.

\section{METHODOLOGY}

This study was conducted by using qualitative research. This study is aimed to investigate the use of semantic rules in finding the lexical meaning in the article of "Gemstone Fever Hits Jakarta."

\section{DATA}

The data source of this study was obtained from the words existed in the article of "Gemstone Fever Hits Jakarta." The total number of words occurred in the article is 546 words, it becomes data of the study. The words to be analyzed are those which have lexical meaning related to semantic relations. There are four semantic relation to be analyzed, they are, synonymy, antonymy, meronymy and hyponymy. It is obtained that synonymies are 34 words; Homonymies are 10; Polysemies are 10 and Hyponymies are 
12 , therefore the total number of words which have semantic relation is 68 , it becomes the sample of the study.

\section{E. TECHNIQUE IN ANALYZING DATA}

In analyzing the data of study, there are four stages were applied by the writer, they are:

1. Initially, the writer counted the total number of words occurred in the article thoroughly without counting how many times the words occur.

2. The writer listed the words which are included in synonymous word, polysemy word, hyponemy word and homonymy word.

3. After finding out the words which has semantic relations, the writer started to look up the lexical meaning of each words in the dictionary which has been selected as resources.

4. The writer put all the words into table to make writer easier to analyze them.

5. Finally, the writer counted the total number of semantic relation words and its percentage toward the whole words in the article.

\section{F. Percentage Counting}

To make a percentage of each semantic relations toward whole the words in the article is very important to find out how much words which have semantic relations exist in the article of "Gemstone Fever Hits Jakarta". Moreover, the way to count the percentage has been designed by the writer herself, as follows:

$$
P_{s r}=\frac{N}{T} \times 100
$$

Where: $\mathrm{P}_{\mathrm{sr}} \quad=$ Percentage of Semantic Relation

$\mathrm{N}=$ Number of Total Semantic Relation

$\mathrm{T}=$ Total number of whole words in the article 


\section{G. Data Analysis}

The data to be analyzed is 34 synonym words, 10 homonym words, 10 polysemy words and 12 hyponymy words. Those are being analyzed as described below:

\section{Synonym}

\begin{tabular}{|c|c|c|c|}
\hline No & $\begin{array}{l}\text { Synonymous } \\
\text { Word }\end{array}$ & Lexical Meaning & $\begin{array}{c}\text { Amount of } \\
\text { Synonymous Word }\end{array}$ \\
\hline \multirow{2}{*}{1} & Astounded & $(v)$ shock or surprise sb very much & \multirow{2}{*}{2} \\
\hline & Amazing & (adj) surprise greatly & \\
\hline \multirow{2}{*}{2} & Rock & $\begin{array}{l}\text { (n) hard solid material that forms } \\
\text { part of the earth' surface }\end{array}$ & \multirow{2}{*}{2} \\
\hline & Stone & $\begin{array}{l}\text { (n) solid mineral substance found } \\
\text { in the ground }\end{array}$ & \\
\hline \multirow{2}{*}{3} & Said & $\begin{array}{l}\text { (v) see SAY. Speak or say } \\
\text { something with words }\end{array}$ & \multirow{2}{*}{2} \\
\hline & Admitted & $\begin{array}{l}\text { (v) see ADMIT. Allow sb/sth to } \\
\text { enter }\end{array}$ & \\
\hline \multirow[t]{2}{*}{4} & Develop & $\begin{array}{l}\text { (v) become or make sth larger, } \\
\text { more advanced }\end{array}$ & \multirow[t]{2}{*}{2} \\
\hline & Trend & (n) general change or development & \\
\hline \multirow[b]{2}{*}{5} & Fondness & (n) having great liking on $\mathrm{sth} / \mathrm{sb}$ & \multirow[b]{2}{*}{2} \\
\hline & Hobby & $\begin{array}{l}\text { (n) activity you do for pleasure in } \\
\text { your free time }\end{array}$ & \\
\hline \multirow{2}{*}{6} & Buy & (v) get sth by paying money for it & \multirow{2}{*}{2} \\
\hline & Purchase & (v) buy something & \\
\hline \multirow[t]{2}{*}{7} & Significant & $\begin{array}{l}\text { (adj) having special meaning; } \\
\text { important }\end{array}$ & \multirow[t]{2}{*}{2} \\
\hline & Priceless & (adj) extremely valuable & \\
\hline \multirow[b]{2}{*}{8} & Fund & (n) amount of money for a purpose & \multirow[b]{2}{*}{2} \\
\hline & Budget & $\begin{array}{l}\text { (n) amount of money that is } \\
\text { available to a person or an } \\
\text { organization and plan of how it } \\
\text { will be spent over a period of time }\end{array}$ & \\
\hline \multirow{3}{*}{9} & Ceiling & $\begin{array}{l}\text { (n) official upper limit: a } \\
\text { price/wage }\end{array}$ & \multirow{3}{*}{3} \\
\hline & Price & $\begin{array}{l}\text { (n) amount of money that you } \\
\text { have to pay for sth }\end{array}$ & \\
\hline & Value & (n) amount of money sth is worth & \\
\hline \multirow{2}{*}{10} & Sensing & $\begin{array}{l}\text { (v) become aware of sth even } \\
\text { though you cannot see it, hear it }\end{array}$ & \multirow{2}{*}{2} \\
\hline & Realizing & $\begin{array}{l}\text { (v) understood or become aware of } \\
\text { sth }\end{array}$ & \\
\hline \multirow[t]{2}{*}{11} & Collect & $\begin{array}{l}\text { (v) come together; bring } \mathrm{sb} / \mathrm{sth} \\
\text { together }\end{array}$ & \multirow[t]{2}{*}{2} \\
\hline & Keep & (v) cause $\mathrm{sb} /$ sth to remain in a state & \\
\hline
\end{tabular}




\begin{tabular}{|c|c|c|c|}
\hline & & or position & \\
\hline \multirow{2}{*}{12} & Have & (v) own, hold or possess sth & \multirow{2}{*}{2} \\
\hline & Own & (v) possess sth & \\
\hline \multirow{2}{*}{13} & Expensive & (adj) costing a lot of money & \multirow{2}{*}{2} \\
\hline & Ceiling price & (adj) very high price of sth & \\
\hline \multirow[t]{2}{*}{14} & Particular & $\begin{array}{l}\text { (adj) relating to one individual } \\
\text { person or thing and not others }\end{array}$ & \multirow[t]{2}{*}{2} \\
\hline & Certain & (adj) particular, but not named & \\
\hline \multirow{3}{*}{15} & Cure & (v) bring sb back to health & \multirow{3}{*}{3} \\
\hline & Relieve & $\begin{array}{l}\text { (v) reduce or remove an unpleasant } \\
\text { feeling or pain }\end{array}$ & \\
\hline & Dispel & (v) cause sth to disappear & \\
\hline \multirow[b]{2}{*}{16} & Popularity & $\begin{array}{l}\text { (n) liked or enjoyed by many } \\
\text { people }\end{array}$ & \multirow[b]{2}{*}{2} \\
\hline & Acknowledged & $\begin{array}{l}\text { (v) accept that sth is true; accept } \\
\text { that sth/sb has a particular } \\
\text { authority or status }\end{array}$ & \\
\hline \multicolumn{3}{|c|}{ Total Number of Synonymous Word } & 34 \\
\hline \multicolumn{3}{|c|}{ Percentage of Synonymous toward Population Words } & $6.2 \%$ \\
\hline
\end{tabular}

\section{Homonymy}

\begin{tabular}{|c|c|c|c|}
\hline No & $\begin{array}{l}\text { Homonymy } \\
\text { Word }\end{array}$ & Lexical Meaning & $\begin{array}{c}\text { Amount of } \\
\text { Homonymous Word }\end{array}$ \\
\hline \multirow{2}{*}{1} & Set & $\begin{array}{l}\text { (v) put sb/sth in a particular place } \\
\text { or position }\end{array}$ & \multirow{2}{*}{ - } \\
\hline & Said & $\begin{array}{l}\text { (v) see SAY. Speak or say } \\
\text { something with words }\end{array}$ & \\
\hline \multirow{2}{*}{2} & By & (prep) at the side of sb/sth & \multirow{2}{*}{2} \\
\hline & Buy & (v) get sth by paying money for it & \\
\hline \multirow{2}{*}{3} & $\mathrm{Had}$ & (v) see HAVE. Hold or possess sth & \multirow{2}{*}{2} \\
\hline & Hat & (n) covering for the hat & \\
\hline \multirow{2}{*}{4} & Price & $\begin{array}{l}\text { (n) amount of money that you } \\
\text { have to pay for sth }\end{array}$ & \multirow{2}{*}{2} \\
\hline & Prize & $\begin{array}{l}\text { (n) award given for winning } \\
\text { competition }\end{array}$ & \\
\hline \multirow{2}{*}{5} & Very & $(a d v)$ to a great degree; extremely & \multirow{2}{*}{2} \\
\hline & Vary & (v) be different in size, amount & \\
\hline \multicolumn{3}{|c|}{ Total Number of Homonymous Word } & 10 \\
\hline \multicolumn{3}{|c|}{ Percentage of Homonymous toward Population Words } & $1.83 \%$ \\
\hline
\end{tabular}

\section{Polysemy}

\begin{tabular}{|c|l|c|c|}
\hline No & Polysemy Word & Lexical Meaning & $\begin{array}{c}\text { Amount of Polysemy } \\
\text { Word }\end{array}$ \\
\hline 1 & Mine & (pron) belonging to me & 2 \\
\hline
\end{tabular}




\begin{tabular}{|c|c|c|c|}
\hline & Mine & $\begin{array}{l}\text { (v) dig coal, etc from holes in the } \\
\text { ground }\end{array}$ & \\
\hline \multirow[t]{2}{*}{2} & Post & $\begin{array}{l}\text { (n) official system used for } \\
\text { sending and delivering letters, } \\
\text { parcels, etc }\end{array}$ & \multirow[t]{2}{*}{2} \\
\hline & Post & (v) send a letter or etc tosb by post & \\
\hline \multirow{2}{*}{3} & Rock & $\begin{array}{l}\text { (n) hard solid material that forms } \\
\text { part of the earth' surface }\end{array}$ & \multirow{2}{*}{2} \\
\hline & Rock & $\begin{array}{l}\text { (v) Move gently backwards and } \\
\text { forwards or from side to side }\end{array}$ & \\
\hline \multirow{2}{*}{4} & Last & (det) coming after all others & \multirow{2}{*}{2} \\
\hline & Last & (v) continue for a period of time & \\
\hline \multirow[t]{2}{*}{5} & Can & $\begin{array}{l}\text { (aux) used to say that is possible } \\
\text { for } \mathrm{sb} / \mathrm{sth} \text { to do sth }\end{array}$ & \multirow{2}{*}{2} \\
\hline & Can & $\begin{array}{l}\text { (n) metal container for foods or } \\
\text { liquids }\end{array}$ & \\
\hline \multirow{2}{*}{\multicolumn{3}{|c|}{$\begin{array}{r}\text { Total Number of Polysemy Word } \\
\text { Percentage of Polysemy toward Population Words }\end{array}$}} & 10 \\
\hline & & & $1.83 \%$ \\
\hline
\end{tabular}

\section{Hyponymy}

\begin{tabular}{|c|l|c|c|}
\hline No & \multicolumn{1}{|c|}{$\begin{array}{c}\text { Hyponymy } \\
\text { Word }\end{array}$} & Hyponymy of & $\begin{array}{c}\text { Amount of Hyponymy } \\
\text { Word }\end{array}$ \\
\hline 1 & $\begin{array}{l}\text { Amethyst, } \\
\text { Bacan, Purple } \\
\text { Amethyst }\end{array}$ & Kinds of Gemstone & 2 \\
\hline 2 & Kinds of Rock & 3 \\
\hline 3 & $\begin{array}{l}\text { South Jakarta, } \\
\text { North Jakarta, } \\
\text { East Jakarta }\end{array}$ & District of Jakarta & 1 \\
\hline 4 & $\begin{array}{l}\text { Gelombang } \\
\text { Cinta }\end{array}$ & Anthurium & 2 \\
\hline 5 & Maluku, Jakarta & Cities in Indonesia & 2 \\
\hline 6 & $\begin{array}{l}\text { Susilo Bambang } \\
\text { Yudhoyono, } \\
\text { Barrack Obama }\end{array}$ & Name of President & $\mathbf{1 2}$ \\
\hline \multicolumn{2}{|l}{ Total Number of Hyponymous Word } \\
\hline
\end{tabular}

Total Percentage of Semantic Relation in the Article of "Gemstone Fever Hits 


\begin{tabular}{|c|c|}
\hline \multicolumn{2}{|c|}{ Jakarta" } \\
\hline Synonym & $6.2 \%$ \\
\hline Polysemy & $1.83 \%$ \\
\hline Homonym & $1.83 \%$ \\
\hline Hyponym & $2.2 \%$ \\
\hline Total Percentage & $12.06 \%$ \\
\hline
\end{tabular}

\section{H. Conclusion}

After analyzed the data, it is found that the article "Gemston Fever Hits Jakarta" has few words which its lexical meaning correlated to certain semantic roles. As four semantic roles are used in analyzing the data, it is obtained that synonym words existed in 34 words, its percentage toward the article is $6.2 \%$; homonym words existed in 10 words, its percentage toward the article is $1.83 \%$; polysemy words existed in 10 words, its percentage toward the article is $1.83 \%$; and hyponymy words existed in 12 words, its percentage toward the article is $2.2 \%$. It is obviously determined that the article of “Gemstone Fever Hits Jakarta” contains mostly of synonym words, which means most of the lexical meaning of the words has the same meaning in the context.

As we may find some other lexical meaning of word in text, speech, article, song and etc, it is really suggested for other learners who would like to conduct the similar study to collect many kinds of dictionary to be resources of study in finding the lexical meaning of words. The learners also may find many words which have semantic relations within its meaning, it is necessary to the learners to enlarge their theories and materials about the semantic relation and its classification.

\section{REFERENCES}

Cruse, D. 1986. Lexical Semantics. Cambridge: Cambridge University Press.

Fromkin, Victoria., et.al. 2007. An Introduction to Language. Boston, MA: Thomson Wadsworth 
Jackson, Howard., Amvela, Etienne Ze. 2000. Words, Meaning and Vocabulary: An Introduction to Modern Lexicology. London: Cassell.

Lyons, John. 1995. Linguistic Semantics: An Introduction. USA: The Press Syndicate of the University of Cambridge.

Meyer, Charles F. 2009. Introducing English Linguistics. New York: Cambridge University Press.

Murphy, M. Lynne. 2003. Semantic Relation and The Lexicon. USA: Cambridge University Press.

Saeed, John I. 1997. Semantics: Chinese Edition. New York: Blackwell Publishers Ltd.

http://www.thejakartapost.com/news/2015/01/31/gemstone-fever-hitsjakarta.html\#sthash.eqXmCQYp.dpuf (Accessed On: Febbruary $4^{\text {th }} 2015.08 .30$ p.m.)

\section{APPENDIX}

\section{Gemstone Fever Hits Jakarta}

When Aris, 40, a Jakarta-based insurance company employee, went to East Kalimantan five months ago to visit a miner client, he was astounded by the sight of a rock outcrop at a coal mine. The client gave him a small piece of raw gemstone found at the site as a souvenir.

"After I had the raw gemstone polished, it turned out to be an amazing amethyst. I wear it as a pendant," Aris said, showing off the purple amethyst pendant in Kebayoran Baru, South Jakarta, on Wednesday. He soon developed a fondness for local gemstones and started to buy more.

"To date, I have collected 10 gemstones," he said, adding that "I can relieve stress just by looking at them.'Realizing that his hobby required significant funds, Aris sets a ceiling price for each gemstone he purchases.

"I set a maximum budget of Rp 5 million [US\$400]. Otherwise, I'll be in trouble with my wife," he said, with a chuckle.

A few years ago, Jakarta and other big cities across the country were rocked by the skyrocketing price of gelombang cinta (waves of love), which is named after a species of Anthurium. Prices reached tens of millions of rupiah. The trend lasted for about two years. The gemstone hobby is actually not new in Indonesia and has lasted for more than one 
decade. The prices vary from about $\mathrm{Rp} 50,000$ to priceless.

Meawnhile, Nesa, 40, a resident of Ancol, North Jakarta, decided to go further to satisfy his curiosity, also sensing a good business opportunity.

"I have collected 200 gemstone rings within about one year. The value of all the gemstones combined may reach Rp 500 million," he told The Jakarta Post. Nesa admitted that most of the gemstones were bought impulsively.

"It's all about curiosity. Once I own the gemstone, the curiosity's gone," he said. However, he did not think the expensive hobby was without benefit.

"It's also a good investment, so I also do this for business," he said, adding that he had secured support from his family.

The bacan gemstone of North Maluku, in particular, has gained wild popularity thanks to reports that former president Susilo Bambang Yudhoyono wore one and even gave one to US President Barack Obama as a souvenir when the latter visited Indonesia a few years ago.

The local gemstone fever apparently has also reached women.

Influenced by friends, self-employed Ira, 38, started the hobby six months ago. "I love gemstones for their color and shape. Some people believe that certain types of gemstone can cure illness, or even can dispel poison," she said.

Untung, a gemstone polisher at Rawa Bening gemstone center in Jatinegara, East Jakarta, acknowledged an increasing number of visitors over the past two years. He was also upbeat the trend would last for a long time. "Because Indonesia's gemstones are unique and amazing," Faizal said.

Another vendor, Ahmad Faisal, had even started his own collection. "When I like a gemstone, I won't sell it, I just keep it to myself instead," he said.

Ahmad even compared gemstones to women. "Falling in love with a gemstone is just like falling in love with a woman. Even though it looks pretty, if we don't feel the chemistry, we won't like it," he said. 